Portland State University

PDXScholar

2016

\title{
A Question of Belief: The Narrative of Joseph Conrad's Lord Jim
}

Madison Wegener

Portland State University

Follow this and additional works at: https://pdxscholar.library.pdx.edu/honorstheses Let us know how access to this document benefits you.

\section{Recommended Citation}

Wegener, Madison, "A Question of Belief: The Narrative of Joseph Conrad's Lord Jim" (2016). University Honors Theses. Paper 328.

https://doi.org/10.15760/honors.325

This Thesis is brought to you for free and open access. It has been accepted for inclusion in University Honors Theses by an authorized administrator of PDXScholar. Please contact us if we can make this document more accessible: pdxscholar@pdx.edu. 
A Question of Belief: The Narrative of Joseph Conrad's Lord Jim

\author{
by
}

\title{
Madison Wegener
}

An undergraduate honors thesis submitted in partial fulfillment of the

\author{
requirements for the degree of \\ Bachelor of Arts \\ in \\ University Honors \\ and
}

English Literature

Thesis Advisor

Jennifer Ruth, $\mathrm{PhD}$

Portland State University

2016 
"Only belief, but not faith, has an inherent affinity with and is constantly exposed to doubt." Hannah Arendt "What is Authority?"

Hannah Arendt's analysis of what constitutes believable authority remains as pertinent today as it was when her essay was first published in Between Past and Future in 1961. In the essay she pinpoints a critical shift in western thinking about authority, belief, and faith at the turn of the 20th century, which has had a profound and lasting impact on the political sphere. While it would doubtless be fascinating to locate echoes of her discussion in our contemporary literature, in this piece I will instead endeavor to examine its relationship with the structure of Joseph Conrad's turn-of-the-century novel Lord Jim. My reading here addresses how the modern struggle to legitimize authority that Arendt discusses is played out in the complex structure of Conrad's narratives in Lord Jim.

Lord Jim was first published as a serial in Blackwood's Magazine, spanning 14 installments between October 1899 and November 1900. Scholars, and Conrad himself, have noted that he originally started the piece as a short story around 1894 . He resumed composition many years later, after completing Heart of Darkness (1899), a fact that has led some scholars to speculate that he could not finish it as a short story, and therefore passed its narration to the character Charley Marlow after four chapters. This sudden shift in Lord Jim 's narrative, from third-person to first-person narration, has provoked a more ambivalent critical response than the similar story-within-a-story framing used in Heart of Darkness. F.R Leavis and others comment that the transition from the introductory narrative to Marlow's tale in Lord Jim is dramatic and clumsy, and likewise, that the overt move to romance in the novel's final section is weak. While it is easy to interpret these features of the novel's structure as haphazard and ham-handed, many scholars since have regarded the structure as characteristic of the modernist novels that rise to prominence early in the $20^{\text {th }}$ century.

Building on the discussions of scholars Reuben Sanchez, Janet Burstein, Tracy Seeley, Jeffrey Williams, and Randall Craig, I maintain that the patchy and disjointed structure of the novel works towards its overall aim as a discursive text, which directly involves the reader in the interpretive process. Conrad's goal for the novel is announced in its prefacing epigraph, quoted from the German romantic Novalis: "It is certain my conviction gains infinitely the moment another will believe in it." This belief, as Arendt stipulates, cannot go unexamined for a modern audience and the discursive design of Lord Jim takes advantage of their doubt by forcing readers to scrutinize how their beliefs about Jim are created. Bernard J. Paris observes of the novel's multiple perspectives that "no one... has more authority than the others" (77). This multifaceted design juxtaposes different narratives, thus recreating Marlow's experience of doubt and ambivalence for the reader. As a result, Conrad's readers become involved on an increasingly personal level as they confront the absence of any reliable authority on Jim.

I argue that the problems posed by "the novel's disrupted chronology, subjective narrators and thematic indeterminacy" (Seeley, 495), as well as its tentative return to romance to solve these dilemmas, are indicative of Conrad's efforts to grapple with the loss of authority at the close of the $19^{\text {th }}$ century. In Between Past and Future (1961), Hannah Arendt contextualizes this loss as a gradual process occurring over the course of centuries, which comes to a head at the close of the $19^{\text {th }}$ and beginning of the $20^{\text {th }}$ century in repeated political revolutions. She views modern political instability as a direct result of the absence of "authority [which] transcends power and those who are in power" (141), an authority that formerly resided in religion and/or tradition, neither of which could be questioned by the general population. This is why she 
commences her preface with Rene Char's aphorism “our inheritance was left to us by no testament," wherein he identifies the disappearance of the unquestionable principles and selfevident standards that ruled the political sphere before modernity. Their disintegration and the resulting epistemological crisis are reflected in the literary movements of realism and modernism, which as Seeley and others (see Sanchez) note, characterize many aspects of Lord Jim, with the exception of the final Patusan section.

This interpretation of the novel attempts to bring together literary and political readings, but in a different sense than Jeffrey Williams' essay. In Theory and the Novel, Williams notes a split in the scholarship on many of Conrad's novels between formal literary readings and historico-political readings (most of which are post-colonial), and he attempts to bridge this divide. By combining Williams' and Craig's discussions of the novel's community emphasis with other, more literary discussions by Janet Burstein, Tracy Seeley and Reuben Sanchez, I intend to explore how the novel epitomizes Arendt's political and theoretical problem of locating authority at the turn of the century, and ultimately turns it upon Conrad's reader as a question of belief.

I begin with a brief overview of the novel's structure, and then examine the omniscient third-person introductory narrative and the ways in which its structure and voice are convincing for readers, but also how it is inherently limited in scope. Next, I address complications to this view that arise in Marlow's first oral narrative, and how they are answered by Stein's metaphor halfway through the novel. Finally, I speak to Marlow's final Patusan narratives and their selfconscious efforts to reclaim Jim. I aim to illustrate that Lord Jim's four-part narrative constitutes a form of dialectic, the movements of which reflect the preeminent problem discussed by Arendt, of legitimizing a secular authority at the close of the $19^{\text {th }}$ century. Belief and truth only become communal projects (as Randall and Williams argue) in the absence of an authority greater than the community, and what Conrad's novel attempts to create is an "authentic and indisputable experience" (Arendt, 91) of Jim's and his own predicament for readers.

Lord Jim is divided among four distinct narratives, each serving a different function in the novel: first, a third person omniscient narrative, then Marlow's oral Patna and Patusan accounts, and finally his letters on Patusan. These fragments fit together into a type of dialectic, and transitions between the narrative fragments require readers to develop a constantly evolving relationship with Jim's story. This relationship seems deceptively simple during the course of the first narrative, but the subsequent narrative complicates and muddles the clarity of the first account, so that much like the novel's title itself, the first half of Lord Jim reveals itself to be of a divided character, split between an omniscient authority ("Lord") and the modernist's colloquial individual perspectives ("Jim"). The Patusan sections of the novel take the argument one step further by introducing a romantic aspect to Marlow's narratives. As a result, the novel is then split again between the outright multitude of perspectives presented in Marlow's Patna narrative, and Marlow's more unified, romantic vision in the ensuing Patusan story. So, while Jim may be the story's object, the novel is primarily concerned with how his story may be constructed, transmitted, and reviewed, chronicling Marlow's struggle as an author to reconcile dissonant perspectives for his audiences, and grappling with his own unassailable doubt about the nature of Jim. Marlow continually wavers between complete uncertainty about Jim, where "he was not - if I may say so- clear to me. He was not clear" (107) and he "passes away under a cloud" (246), and firm assurances that Jim "had a achieved greatness" (136) and is "one of us." Such vacillation is echoed by the overall design of the novel, which affects a series of movements 
between different ideas of authority and modes of making meaning. In this way, the narrative structure functions as a prism for Conrad's reader, forcing them to join Marlow's struggle - that to make one true, believable Jim from many conflicting viewpoints.

Conrad's purposefully limited use of the third-person omniscient perspective indicates that Lord Jim would differ if this particular authorial voice were sustained throughout the novel. The first four chapters, which occupy a mere 17 pages $^{1}$, contain an essentially complete omniscient third-person account, and provide a striking contrast to the narratives that follow. This section covers Jim's entire life, and functions superficially as a frame narrative, providing a context for Marlow's spoken and written accounts that make up most of the remaining 222 pages $^{2}$. Despite its primary function as a frame, the introduction of Marlow's narratives at the close of the omniscient account is sudden and disorienting for first-time readers of the novel. The audience find themselves abandoned almost entirely to Marlow's first-person narration and endless doubt about Jim, making for a jarring change in style and content. The all-seeing or "omniscient" aspect of the third-person narrative is convincing, but makes the transition problematic because it appears to know and reveal every material aspect of the story. This in turn causes alternative perspectives, like Marlow's first person narrative, to appear limited and biased in comparison. Through appearing to provide an absolute or objective vantage, in Lord Jim, the omniscient perspective simplifies the reader's vision to that of one 'true' Jim; this is the same version of Jim identified by the Official Patna Inquiry, who is known through certain codified, unquestionable facts. Subsequently, the first narrative revolves around these fatal facts, and sets up a clear dichotomy between Jim's objectively 'real' and subjective 'ideal' selves, insisting that the gulf between them cannot be bridged. It presents an authoritative and static view of Jim who was, and will always remain a coward, irreparably barred from realizing his ideal self by the Inquiry's law, represented by the "serried circle of facts that had surged up all about him to cut him off from the rest of his kind" (23). Conrad's choice to relay the narrative to Marlow then challenges the verity of any one authoritative account by raising doubts about the true objectivity of the Official Inquiry and third-person omniscient perspective.

It is no coincidence that the word 'fact' pervades the first and last chapters (1 and 4) of the omniscient narrative, and that like the third-person perspective and Official Inquiry, it represents a certain type of "constituted authority" (38). This legal authority possesses the power to make Jim's subjective or mythic experience "irrelevant" (23) and thus cements the dichotomy between the two. In Arendt's understanding, this variety of authority derives its legitimacy from a

“...code which was made either not by man at all... or at least not by those actually in power... a force external and superior to its own power; it is always this source, this external force which transcends the political realm, from which the authorities derive their "authority," that is, their legitimacy, and against which their power can be checked." (97)

\footnotetext{
${ }^{1}$ This is a mere 7.1 percent of the whole novel, and only occupies the first Blackwood's installment. Page numbers in this essay refer to the Norton Critical Edition of Lord Jim (1996)

${ }^{2}$ Over 90 percent of the entire novel.
} 
This supervening, disembodied authority, which has the power to legitimize man's laws, is different than that of common subjective experience to which Marlow will appeal, and which is associated with his first-person narration. The third-person narrative used in this section is characteristic of the 'objective' discourse of facts from which the Official Inquiry derives its authority. Facts, like the third-person omniscient narrative, should be transparent, unquestionable, absolute, and true, but Conrad recognizes the legal system as a discourse much like any other. The limits and construction of this objectivity, and subsequently its authority, become apparent during the Official Inquiry. Here, the "truth of [Jim's] experience" (38) is purposefully silenced because the question at hand is not that of a holistic truth, but of his legal guilt or innocence, which can be established through the "superficial how" (38) consisting of a few simple and relevant facts. That the ship did not sink, and Jim jumped are all that matters; "the fundamental why" (38) of it all - what Jim experienced, is immaterial to the court of Inquiry. Jim repeatedly becomes "irrelevant," (23), despite his protestations that his experience was of the utmost importance:

"The facts those men were so eager to know had been visible, tangible, open to the senses, occupying a place in space and time...they made a whole that had features, shades of expression, a complicated aspect that could be remembered by the eye and something else besides, something invisible, a directing spirit of perdition that dwelt within like a malevolent soul in a detestable body." (23)

By juxtaposing two disparate ideas of truth in this passage, Conrad identifies the limitations of the Inquiry and the objective discourse with which it is associated. This discourse denies access to Jim's internal experience of the Patna incident, and reveals only half of the story. Speaking to this, and other passages like it, Janet Burstein and Tracy Seeley refer to the same thing when they discuss Jim's romantic imagination (Seeley), and mythic way of knowing the world (Burstein), which is ultimately to blame for his fear aboard the Patna and subsequent expulsion from his craft. This mythic/romantic experience is the truth of the situation for Jim, but during the Inquiry, Jim's mythic way of knowing cannot vindicate him because his subjective experience - the reason for his actions - is irrelevant, and "speech [becomes] of no use to him any longer" (24). The fear that crushed his romantic ideal is outside the jurisdiction of the court of Inquiry, even if it is highly relevant to the people in the courtroom, who are all potentially at risk for the same disaster (38).

This first version of the story is limited in scope as a result of its narrative perspective, focusing primarily on Jim's brief career as a sailor and the official inquiry that ends it, only mentioning the Patna and Patusan episodes in passing. It is true in the factual, objective sense, but it also seems biased through its omissions, and in its conclusion that Jim's movement to Patusan was a flight, and further evidence of his cowardice "when his keen perception of the Intolerable drove him away for good from sea ports and white men... where he has elected to conceal his deplorable faculty" (8). Despite the apparent logic of this conclusion, Conrad's reader, like Marlow, is left with the feeling that there must be more to the story (in fact, 222 pages more). The first narrative announces its own inadequacy by depicting the Inquiry's overt silencing of Jim's perspective, while simultaneously excluding and writing it off as immaterial and irrelevant for the same reasons when it concludes that Jim remains a coward in Patusan. 
The omniscient narrative fails to retain a modern audience's trust by complicitly silencing and invalidating Jim's perspective. This leaves it vulnerable to Marlow's challenge in the ensuing narratives, which will point to the inadequacy of a disembodied authority, and eventually aim to synthesize the real and ideal concepts of self for Jim. Accomplishing this synthesis, and making his audience believe it is possible, will be Marlow's goal throughout the rest of the novel. He will endeavor to establish his authority first, by casting doubt over the omniscient narrative's conclusion, and then by returning to the romantic tradition and asking the audience to believe in spite of doubt. The belief that Marlow asks of his audience is different than the blind faith required by the omniscient narrative and laws of the Official Inquiry. When Arendt speaks of belief, she describes an open discourse where doubt, and questioning are permitted and encouraged, which is much different than the closed discourse of faith. Faith requires the silencing and omission of contradictory information, which in itself reveals weakness. Any authority that cannot stand scrutiny or contradiction clearly does not wield the power or legitimacy it would purport to have, and thus fails the test of modernity. When Marlow appeals to his audience, he does so not from outside and above common experience (a theoretical perspective, that, like the omniscient third-person, has no real-world analogue), but from the common experience of each listener/reader, repeatedly referring to Jim as "one of us." This relocation of truth from above and outside the self or community, to inside the community and its individuals is at the heart of the loss of authority Arendt describes.

\section{II}

In this section, I discuss how Marlow rigorously interrogates the third-person omniscient's dichotomy between the 'true' and 'false' Jims in his first narrative. Together these two sections comprise the Patna half of the novel, which is split between the clear conclusion of the third-person omniscient narrative and the profuse catalogue of testimonies compiled by Marlow during his first oral account ${ }^{3}$. Through this movement, Conrad pits empirical and experiential epistemologies against one-another, implying that neither can be complete without the other. As a result, the first half of the novel presents a modernist dilemma to which there is no satisfactory answer, no synthesis of opposed views, despite the second narrative's successful obfuscation the first's simple dichotomy. The break between the two Patna narratives amplifies the novel's emphasis on perspective and forces the reader to reflect on the location of authority and truth in Lord Jim. The omniscient account clearly condemns Jim as a coward, and claims objectivity and impartiality through the third-person narration, whereas Marlow's first narrative seeks consensus from numerous subjective accounts. None of these agree with one-another, nor with the omniscient account, leading Conrad's reader to doubt the validity of the omniscient's conclusion, without providing a satisfactory replacement for it.

The omniscient account's authoritative status is abandoned first by the epitaph prefacing Lord Jim, and then by Marlow's sudden introduction as the primary narrator. In his Patna narrative Marlow relies upon inter and intra-personal realities that fail to converge upon any one understanding of Jim. He opens his story for an anonymous audience noting that the Patna incident is common knowledge amongst seamen (29-30), and stakes his own authority on Jim's acquaintance and common sympathy: He knew Jim, and understood his predicament. From this privileged position of "authentic and indisputable experience" (Arendt, 91), Marlow takes over

\footnotetext{
${ }^{3}$ See Jeffrey Williams, page 167 for a comprehensive list of these accounts.
} 
Jim's story and attempts to recreate this experience for his audience. In "Swapping Yarns: The oral Mode of Lord Jim," Randall Craig, drawing on the work of Walter Benjamin, argues that use of the told tale device in Lord Jim privileges interpretation:

"The oral tradition appeals to Conrad for ... its conventional lack of concern with factual information. For Conrad, truth is a matter of multiple and conflicting interpretations, not objective and unitary fact..." (183)

He further suggests that the "interludes" (185), or subsequent appearances of the omniscient narrative work to integrate Conrad's reader with Marlow's audience by creating a sense of interpersonal connection with the narrator and thus the story. Expanding on Craig's assertion, the omniscient narrator transports Conrad's reader into his audience by the speculative tense, so that the telling could recur at almost any time, when "...later on, many times ... Marlow showed himself willing to remember Jim...", "Perhaps it would be after dinner..." (24), or "[Marlow] would say" (25). Thereafter, this voice appears only six times, in the past tense during Marlow's oration: "Marlow paused... and abruptly began again" (59), "He paused again...murmured-" (60), "Marlow sat up abruptly.... Nobody stirred." (70), or "Marlow paused...Nobody spoke" (193). Such interjections remind Conrad's reader of their position relative to Jim's story, and of Marlow's position as storyteller, integrating them with his audience. The limited function of the omniscient voice requires Conrad's reader to rely solely on Marlow's perspective. In this way Conrad rejects the third-person omniscient in favor of Marlow's first-person account, and highlights the epistemological inadequacies of the third-person omniscient voice if it provides no real world analogue on which to model the narrator's point of view. The third-person omniscient perspective is less believable for a modern audience because it lacks the nuance and complexity of a first-person account, as well as a point of connection for the audience. The contrast between these two narratives also highlights the role language and discourse play in determining meaning, and destroys the illusion of objectivity when it is revealed to be a construct of 'detached' language, rather than a legitimate perspective.

It is interesting to consider the use of oral tale in the novel as enacting a throwback to more traditional forms of authority identified by Arendt ${ }^{4}$, but the first-person presentation and plethora of testimonies in the first oral narrative is distinctly modernist. So, we are then faced with authority in a modernist text deriving from an ancient tradition of oral narratives, a tradition that frames truth as a "communal project in which teller and listener each have a part" (Craig, 186). Viewed this way, the transition from the omniscient narrative into Marlow's spoken accounts can be assumed to be purposefully jarring, thus furthering the rhetorical purpose with which Craig is concerned. The construction of meaning in Lord Jim is a democratic process, which according to Arendt, predates the concept of authority (104) in its original Greek form, as she quotes Aristotle "the polis is a community of equals..." (116). Marlow's continuous vacillation between certainty and doubt about Jim, and his repeated appeals to the audience to "see" operate on "the assumption that what makes men human is the urge to see" (Arendt, 114115), and that the audience to whom he appeals is composed of his equals. Marlow does not hand down judgment the way the Inquiry does, but he requests consensus from those around him, recognizing the loose footing of any claim to absolute authority in the modern era. His appeal is

\footnotetext{
${ }^{4}$ See pages 122-124. Craig also mentions "The attractiveness of the oral performance as a model for the novel must be seen in terms of Conrad's conception of his readership. Thee writer's appeal must be catholic..." (182)
} 
instead to the tradition, and the oral tradition asks that he draw on common experience to achieve his goal.

In his essay, Sanchez remarks that "Jim's life therefore evokes the dichotomy between good and evil in a man, and it is the realization of this dichotomy that bothers not only Marlow, but other characters - and perhaps - the reader as well." (68) This particular dichotomy, codified by the results of the Inquiry takes on emblematic importance even in the first chapter, when Jim is described as looking and seeming like "the right sort" (50), and "he knew what to think" (11), yet he fails repeatedly to be the "example of devotion and duty, as unflinching as a hero in a book" (9) that he and others desire him to be based on his "sound" (29) ideology and appearance. The omniscient narrative's conclusion, that Jim's leap from the Patna creates an unbridgeable schism, is fatalistic because it posits no solution or hope of redemption for him or others like him. If we are all inherently at risk of the same failure as Sanchez suggests, then the assurance of consequences and absence of a solution reveals the legal basis of Jim's expulsion to be untenable. When Marlow speaks of the Inquiry, he points to this same inadequacy, describing his desire for a violent affirmation, as he "waited to see [Jim] overwhelmed, confounded, pierced through and through, squirming like an impaled beetle..." (30). Such desire for a spectacle, as Arendt points out, can only arise from the "confusion... of legitimate power with violence" (97), when the state (and legal system supporting it) exacts physical dominance where it failed to rule effectively or establish legitimate authority.

Continuing this thread, Marlow hints that the failure is inherent in the empirical discursive method behind the Inquiry itself, which it shares with the medical profession. The use of the third-person voice is a feature of this method, which attempts to remove any trace of the speaker/writer, and thus increase its objectivity (and authority) by doing so. To Conrad, this is an inherently false perspective, lacking the human connection and access to meaning he seeks through Marlow's first-person narratives. During Marlow's meeting with the chief engineer and his physician in the hospital, he finds the medical inquiry into the chief engineer's alcoholic delirium lacking in the same way as the Official Inquiry into Jim's case - concerned with the "superficial how" (his physical condition) rather than the "fundamental why" (his emotional condition) of the situation. He subsequently remarks of the Inquiry "You can't expect the constituted authorities to inquire into the state of a man's soul - or is it only of his liver? Their business was to come down upon the consequences..." (38) The physician and Inquiry are unconcerned with the intangible causes of the chief engineer's drunkenness, or Jim's jump, "which [to Marlow] would have been the only truth worth knowing" (38). To Marlow's chagrin the physician and Inquiry purposefully circumvent this truth and instead assess and address the "consequences," which is of no help to the subjects of their study. Like the doctor's futile musings about the "method in [the chief engineer's] raving" (37), the Inquiry "was as instructive as the tapping with a hammer on an iron box were the object to find out what's inside" (38). Such oversight of the internal state results in diagnoses that are just as shallow. The engineer has delerium tremens, rather than alcoholism or depression, and Jim is a coward, rather than an imaginative romantic. This is likely why the plight of the chief engineer is the same one Marlow fears for Jim, if the community around him fails to recognize cause (alcoholism or depression) and instead concerns itself only with the effect (delerium tremens):

"I was concerned as to the way he would go out. It would have hurt me if, for instance, if he had taken to drink. The earth is so small that I was afraid of, some day, being waylaid by a blear-eyed, swollen-faced, besmirched loafer, with no soles to his canvas shoes, and 
with a flutter of rags about his elbows, who, on the strength of old acquaintance, would ask for a loan of five dollars... That, to tell you the truth, was the only danger I could see for him and for me..." (171)

Marlow implicates himself in this last sentence because he perceives that he is a member of the same human community whose inherently flawed discourse excommunicates Jim and the experience he represents when, as he admits, "These were issues beyond the competency of a court of inquiry..." (59). The outcome proves dire not only for Jim, but for the other members of the community, including Brierly, who seems to perceive the spectacular nature of the inquiry when he asks to Marlow "Why are we tormenting that young chap?" (43) and proceeds to offer him money to find somewhere to remove Jim because "This infernal publicity is too shocking... Why Marlow, don't you think, don't you feel, that this is abominable; don't you now - come as a seaman?" (44). As the overseeing authority at the Inquiry, Brierly commits suicide shortly thereafter out of discomfort with its outcome: the proscription of subjective truths, and even the question of their existence, in the interest of an objective legal discourse. He sees his own potential for fallibility in Jim, as Marlow astutely observes (Sanchez, 69), and cannot come to grips with condemning Jim; the authority itself commits suicide in the person of Brierly when its own agents are found guilty. Marlow's narratives and final story realize the missing truth of a reality constituted through human contact, to which Brierly appeals during his interview with Marlow when he amends "don't you think" to "don't you feel" (44).

Even though Marlow claims a privileged perspective on Jim, his first oral account fails to formulate the 'truth' he and Jim found lacking at the inquiry, and his quest for the second opinion during this narrative never arrives at a consensus. Instead he merely manages to deconstruct the tidy dichotomy of the omniscient narrative, forcing his audience to look upon "the convention that lurks in all truth and on the essential sincerity of falsehood" (59). The latter half of this vision only appears to his audiences in the ensuing Patusan narratives. In this first half of the novel, Marlow and his authorship become more real to the reader than Jim, creating a story about the subjective experiences of knowing Jim, rather than about Jim as a character. Such a tactic relays Marlow's bewilderment to an audience that previously possessed the illusion of a satisfactory conclusion, and forces them to examine the epistemological modes operating behind each version of the Patna story (Williams, 172-173).

While many critics (such as Craig) have regarded Marlow's oral narrative as a single, cohesive piece, and argue that his written narrative is the romantic conclusion, I agree with Frederic Jameson who argues that the "text pivots on the hinge of generic opposition between the modernist first half... and the heroic romance of the second half" (Williams, 174). Like Jameson, I regard the oral narrative as broken into two parts by Marlow's meeting with Stein, observing a distinct turning point during the section with Stein. Marlow's second oral narrative and the written account both focus the reader's attention forward to Patusan, working to synthesize the divergent perspectives and successfully bridge the epistemological schism presented in the Patna account. Here it may be interesting to note that the novel was published in 14 installments in Blackwood's, which are split almost evenly by Marlow's interview with Stein. Furthermore, the pacing of the chapters picks up, and the installments become longer on average after this 
interview $^{5}$, no doubt reflecting the shift from a dialogue-based to a plot-based narrative. Stein's position halfway through the novel, and the resolution that follows it both physically and theoretically link the multitude of individual perspectives in the first oral narrative with the first omniscient narrative, so that Marlow's synthesis in his final two narratives is distinguished from them. Williams summarizes Jameson's view as the "structural displacement of modernism for the comfort of romance," (174) but I would hesitate to describe the second half of the novel as comfortable with romance. I contend that the power of these narratives lies in their profound discomfort with romance (Arendt's doubt), and subsequent appeals to the audience to believe. Marlow's meeting with Stein halfway through the novel functions as a thematic and epistemological fulcrum, providing both practical and theoretical solutions to the conundrum of what to do with Jim. Stein's authority seems to derive from his status as a seasoned elder, as Marlow describes him on pages 122 and 130. This fits with Arendt's conception of authority derived from tradition, or "growth directed toward the past" (123), and those who represent it: "The authoritative character of the "augmentation" of the elders lies in its being mere advice, needing neither the form of command nor external coercion to make itself heard." (123). Their advice, much like Stein's, requires neither power nor argument (as the Inquiry does) because it has been legitimated by age. This sense of authority, alongside Stein's vast life experience, impels Marlow to seek his counsel:

"His wealth and respectability were not exactly the reasons why I was anxious to seek his advice. I desired to confide my difficulty to him because he was one of the most trustworthy men I had ever known. [...] I, who knew [of his life or character], considered him an eminently suitable person to receive my confidences about Jim's difficulties as well as my own." (122-123)

Stein carries authority not only because of his age, but his connection to a tradition - the ideology of heroism. He is a relic of old imperial adventure, and based on Marlow's account of his life, could easily have been one of the men who inspired tales from the light literature of Jim's youth. Stein seems "eminently suitable" because, unlike the French Lieutenant or Brierly, his exploits reach beyond the simple performance of duty and are tinged with the "recklessness" (122) of romantic adventure. This past ties him to the mythic epistemological tradition identified by Burstein, which is the basis (the 'imagination') for the romantic genre described by Seeley. Marlow's meeting with Stein is, then, directed toward the past on multiple levels, and this backward-looking trend of growth is reflected in the novel's leap from hyper-modernist to romantic narration after Stein's insight about Jim. In her introduction to Between Past and Future, Arendt draws on the words of William Faulkner (another, later modernist writer) to describe, in general terms, this counter-intuitive movement, which we may observe in the narrative structure of Lord Jim:

"In the words of Faulkner, "the past is never dead, it is not even past." This past, moreover, reaching all the way back into the origin, does not pull back, but presses forward, and it is, contrary to what one would expect, the future which drives us back into the past." (10)

\footnotetext{
${ }^{5}$ The first half of the novel averages 12.28 pages per Blackwood's installment, and the second half 19.85 pages per installment.
} 
The desire to create a future for Jim, and to find some solution to the chasm created by his jump from the Patna drive Marlow to seek answers from the past, which in this case is the romantic tradition represented by Stein. While Stein admits that he missed opportunities in much the same way Jim did, he also understands that this is a common experience for those who, like Jim are "romantic" (128) and advises that persistence is the only way through: "That was the way. To follow the dream and again to follow the dream - and so - ewig - usque ad finem..." (131). This is how one submits oneself to the "destructive element," (129), which is the central message of Stein's metaphor. His advice has implications for both Marlow and Jim, who each have a romantic ideal at stake in the story. During their interview, it is implied that Jim is in some way Marlow's butterfly, when, after perusing Stein's collection (and in particular his most valuable specimen) he introduces his subject thus: "To tell you the truth Stein ... I came here to describe a specimen..." (128). Although Stein insists to Marlow "You don't know what it is for a collector to capture such a rare specimen. You can't know." (126), it is this very thing, which brings Marlow to consult Stein. If Marlow is a storyteller or poet (as Craig argues), then the realization of his idealized self hinges on the ability to share a vision and its hero, as well as on his empowering realization in the second oral narrative that "[Jim] existed for me, and after all it is only through me that he exists for you." (136).

Thomas Moser, the editor for the Norton Critical Edition of Lord Jim notes that Conrad likely culled the novel's epitaph not from its original source (Novalis), but from Thomas Carlyle's On Heroes and Hero Worship, providing further evidence that he was considering heroic romance as a problem of authorship and discourse while composing the text. This also explains why, during Marlow's visit with Stein, his advice about submitting to the "destructive element" is shared exclusively with Marlow. As the sole recipient of this advice, Marlow, not Jim, is singled out for straying from his dream; it is Marlow's decision to take Stein's advice that provides both himself and Jim with the means to realize their ideals. Marlow must first believe in spite of doubt if he is to convince anyone else that Jim is "one of us," because, as his first oral narrative demonstrated, simply casting doubt upon the character of the Patna episode cannot make Jim a hero. Marlow and Jim will therefore be driven into the past not only theoretically, but physically as well, when Marlow describes Patusan as a sort of primeval location and landscape in his second oral narrative:

"The coast of Patusan... is straight and sombre, and faces a misty ocean. Red trails are seen like cataracts of rust streaming under the dark green foliage of bushes and creepers clothing the low cliffs. Swampy plains open out at the mouth of rivers with a view of jagged blue peaks beyond the vast forests. In the offing a chain of islands, dark, crumpling shapes, stand out in the everlasting sunlit haze like the remnants of a wall breached by the sea." (146)

Given his naturalistic description, it comes as no surprise that "...utter insecurity for life and property was the normal condition" $(138)^{6}$. The necessity of Patusan lies not only in its physical remoteness, but in its seeming chronological remoteness as well. It is a place, both physically and theoretically beyond the reach of courts of inquiry, empirical discourse, and "the haggard utilitarian lies of our civilization" (168), functioning by an altogether different and archaic set of rules. Thus it provides a fitting context both for Jim's heroism and for Marlow to locate his tale.

\footnotetext{
${ }^{6}$ This draws a strange parallel to Thomas Hobbes' "state of nature," or state of man before social contracts of any kind.
} 
Having established the appropriate setting with Stein's assistance, Marlow's second oral account and letters return to a plot-oriented narrative that tragically (241) recounts Jim's life and death in Patusan, much like the heroic adventures he envisions early in the omniscient narrative. ${ }^{7}$ The tone, as well as epistemological focus of this narrative shifts dramatically with the introduction of Patusan, when Marlow opens by stating:

"I affirm he had achieved greatness; but the thing would be dwarfed in the telling, or rather in the hearing. Frankly, it is not my words that I mistrust, but your minds. I could be eloquent were I not afraid you fellows had starved your imaginations to feed your bodies." (136)

This privileging of imagination (or the 'mythic') begins the final shift in the novel's narrative. Here, Marlow insists that his audience accept, or at least entertain that discourse which was forbidden at the inquiry and missed by his first oral narrative. Stein's elder status reintroduces authority to this mythic epistemology, such that it now speaks to tradition and can no longer be ascribed to the folly of youths (like Jim). Furthermore, the relocation of the story moves it outside the boundary of those empirical and modernist-relativist discourses that disqualified the mythic-romantic truth. Patusan is identified discursively by its affinity to "legend" (159) and the "popular story" (161), which are created, agreed upon, and passed on by a community whose imaginations are alive and well, as Jim notes as Jim observes "They will sit up half the night talking bally rot, and the greater the lie the more they seem to like it"... he said and burst into a Homeric peal of laughter." (160). Marlow reinforces this epistemological leap and his own position in the oral and poetic traditions with repeated allusions to Homer's Odyssey on pages 187-188: “...but if the spirits evoked... have ever to vouch for each other's constancy...", "My part was to speak for my brother from the realm of forgetful shades", and "...winged words of truth...". These allusions are echoed in the closing statement of his letter, when he asks "... and I have I not stood up like an evoked ghost, to answer for his eternal constancy?" (246), and once again aligns himself with the heroic tradition and the authority it represents.

While the second oral narrative nonetheless concludes abruptly and ambiguously with the rapid dispersal of Marlow's remaining audience, it is quickly resumed in his letters to the privileged reader, which recount the tale of Jim's death. I regard Marlow's transition here from an oral to a written method as an effort to "overwrite" the Inquiry's decision in the first account. If, as Marlow notes "there was not the thickness of a sheet of paper between the right and wrong of this affair" (80), then he is using the written word to solve this - writing the opposite to right the record and framing his final narrative thus:

"...I felt that tomorrow, when I had left [Patusan] forever, it would slip out of existence to live only in my memory till I myself passed into oblivion... perhaps it is that feeling which has incited me to tell you the story, to try and hand it over to you as it were, its very existence, its reality - the truth disclosed in a moment of illusion." (192)

When we reflect that Marlow proceeds to close his letters by mentioning Stein's legacy ("Stein has aged greatly of late. He feels it himself, and says often that he is 'preparing to leave

\footnotetext{
${ }^{7}$ When introducing the letters, Marlow quotes Jim: "I have no hesitation in imparting to you all I know of the last episode that, as he used to say, had "come to him"” (259). The root of the modern English word "adventure" is the French "ad venire," which translates "to come." This phrase "come to" is repeated frequently in the last half of the novel by both Jim and Marlow.
} 
all this; preparing to leave, ...' while he waves his hand sadly at his butterflies." (246)), then it is apparent in the opening passage that through his letters, Marlow is once again following Stein's lead by preserving and passing on his own specimen, the romantic experience of Jim. Quoting an unnamed source, Arendt describes the purpose of leaving such a testament thus "Action that has meaning for the living has value only for the dead, completion only in the minds that inherit and question it." (6). Continuing this thread, she defines completion as the remembrance, retelling, and understanding of the event by future generations: "to understand what happened...according to Hegel, is man's way of reconciling himself with reality" (7). Achieving this type of reconciliation is the ultimate aim of Marlow's tales in Lord Jim. Despite his often tentative tone, repeatedly addressing the doubts of the letter's recipient in the opening passage (201), and questioning the nature of the story's outcome (246), Marlow boldly affirms Jim's heroic, and his own poetic identities by speaking and writing. The doubtful, or "gnostic" (Seeley) element of Marlow's Patusan romance(s) performs a synthesis by acknowledging alternative perspectives that may be more objectively real, but asking his audiences to believe that the romance and the illusion can be equally true.

\section{IV}

If Lord Jim consisted only of romance, there would be no dissonance to conquer, and Conrad's reader would be bound by the faith of fiction and its implicit agreement to set aside doubt and suspend disbelief. Instead, the discursive structure of the novel solicits this dubious response, asking readers to weigh what is lost when we turn our backs to imagination and romance entirely, as Marlow chides his audience "I do not mean to be offensive; it is respectable to have no illusions - and safe - and profitable - and dull. Yet you too in your time must have known the intensity of life..." (136). The value of submitting to the illusion, to the "destructive element" is the creation of meaning, because, as Stein (and Seeley) note, the destructive and generative element are one and the same; in Stein's metaphor the same "deep, deep sea" (129) that can drown an inexperienced man also keeps him afloat if he simply treads water.

Throughout Lord Jim, Conrad brings attention to an ever-present obstacle between his audience and subject in the form of discourse, such that the focus of Lord Jim is not Jim himself, but what to do with respect to Jim. The novel's narrative shifts repeatedly, from empirical, to modernist, and finally romantic/mythic discourse. These changes situate the reader between past and present constructions of truth, and force them to confront a similar loss of authority to the one Arendt describes. The brevity of the third-person omniscient account, in contrast with Marlow's profuse, ongoing generation of narratives gracefully illustrates her point about the vacuum left when tradition, its authority, and its truthful illusions are lost, leaving the mind of man to "wander in obscurity" (6):

"Without testament...without tradition - which selects and names, which hands down and preserves, which indicates where the treasures are that what their worth is - there seems to be no willed community in time and hence, humanly speaking, neither past nor future, only sempiternal change of the world and the biological cycle of living creatures in it." (5) 
Marlow's letters attempt to provide this testament and build a community around it by acknowledging to his audience that doubt is an essential part of their choice to believe. Despite Marlow's momentary assurance that "Nothing mattered, since I had made up my mind that Jim, for whom alone I cared, had at last mastered his fate. He had told me he was satisfied..." (193), he concludes his letters with the question "Is he satisfied—quite, now, I wonder?" (246). Jim's self-reported satisfaction is not validated for Marlow without the assurance of the community around them, the narrative audience, to whom Marlow's addresses his phrase "one of us." He asks his audience to examine the evidence he presents, and to believe, in spite of their doubts, that Jim has achieved heroic status. This differs from an appeal to faith, which is validated by an unquestionable discourse that requires no evidence, and dogmatically ignores, rather than integrates, evidence to the contrary. Lord Jim's complex narrative structures assimilate Conrad's reader into Marlow's collective "us" by forcing them to confront a heterogeneous experience of Jim, as he appears through the omniscient, individual, and mythic-romantic perspectives. The multiplicity of potential authorities in the narrative destroys the possibility of identifying an objectively true view of Jim, and poses Arendt's problem of locating authority for Conrad's reader. Thus, like Marlow, readers must decide for themselves whether Jim mastered his fate. 
Works Cited:

Arendt, Hannah. Between Past and Future: Six Exercises in Political Thought. New York: Penguin Classics, 2006. Print.

Burstein, Janet. "On Ways of Knowing in Lord Jim." Nineteenth-century Fiction. 26.4 (1972): 456-468. Print.

Conrad, Joseph. ed Thomas C. Moser. Lord Jim: An Authoritative Text, Backgrounds, Essays in Criticism. New York: W.W. Norton \& Co, 1996. Print.

Craig, Randall. "Swapping Yarns: The Oral Mode of Lord Jim." Conradiana 13.3 (1981): 181193. Print.

Paris, Bernard J. Conrad's Charlie Marlow: A New Approach to "Heart of Darkness" and Lord Jim. New York, N.Y: Palgrave Macmillan, 2005. Print.

Sanchez, R. "Conrad's Serried Circle of Facts in Lord Jim." Conradiana. 43.1 (2011): 61-83. Print.

Seeley, Tracy. “Conrad's Modernist Romance: Lord Jim.” ELH 59.2 (1992): 495-511.

Williams, Jeffrey. Theory and the Novel: Narrative Reflexivity in the British Tradition. Cambridge, U.K: Cambridge University Press, 1998. Print. 